Thabiea : Journal of Natural Science Teaching
Program Studi Tadris Ilmu Pengetahuan Alam
Institut Agama Islam Negeri Kudus
http://journal.stainkudus.ac.id/index.php/Thabiea
$p$-issn: 25808474

\title{
Profil Keterampilan Proses Sains Fisika Siswa SMA di Kota Lubuklinggau pada Pokok Bahasan Listrik Dinamis
}

\author{
Yaspin Yolanda a, , Ahmad Amin ${ }^{\mathrm{b}, 2 .}$ \\ aSTKIP PGRI Lubuklinggau, JL.Rambutan Taba Jemekeh Lubuklinggau, 31628 \\ bSTKIP PGRI Lubuklinggau, Perumnas Nikan BlokA5. No.21 Lubuklinggau, 31630 \\ 1'yaspinyolanda@ymail.com; ${ }^{2}$ aminyubi@gmail.com
}

\begin{tabular}{l} 
Kata kunci: \\
\hline Listrik Dinamis \\
Kontekstual \\
Keterampilan Proses Sains
\end{tabular}

\begin{abstract}
ABSTRAK
Penelitian ini bertujuan mendeksripsikan profil keterampilan proses sains (KPS) fisika siswa di SMA Kota Lubuklinggau pada materi listrik dinamis. Subjek penelitian adalah siswa SMA kelas XII semester ganjil di sma Negeri 1, MAN 1 Model dan SMA Negeri 5 di Lubuklinggau. Pengambilan sampel dilakukan secara purpossive sampling. Metode Deskriptif kualitatitif. Data dianalisa secara kualitatif dan kuantitatif. Berdasarkan hasil data penelitian KPS fisika siswa kelas XII IPA pada pokok bahasan Listrik Dinamis disimpulkan (1) Keterampilan proses sains fisika siswa pokok bahasan listrik dinamis adalah terampil, dan (2) Solusi untuk menyelesaikan permasalahan ketersediaan aspek KPS adalah melatih dan dilatih dengan pendekatan KPS fisika siswa agar ketersediaan aspek KPS siswa dapat muncul/tersedia. Adapun aspek KPS yang perlu dilatih dan melatih adalah keterampilan klasifikasi, mengkomunikasikan, berhipotesis, menerapkan konsep, bereksperimen, menggunakan alat dan bahan, interprestasi dan mengajukan pertanyaan. Persentase peningkatan KPS yakni, keterampilan observasi 90,3\%, keterampilan klasifikasi $85,3 \%$, keterampilan interpretasi $87,2 \%$, keterampilan prediksi $80,4 \%$, keterapilan merencanakan percobaan atau penyelidikan 92,6\%, keterampilan menggunakan alat dan bahan 92,1\%, keterampilan menerapkan konsep atau prinsip 82,3\%, keterampilan berkomunikasi $89,4 \%$, keterampilan mengajukan pertanyaan $95,1 \%$, dan keterampilan berhipotesis $81,2 \%$. Sehingga secara keseluruhan terjadinya peningkatan yang signifikan $87,3 \%$ KPS siswanya.
\end{abstract}

\begin{tabular}{l}
\hline Key word: \\
\hline Dynamic electricity \\
Contextual \\
Science Process Skills
\end{tabular}

\section{ABSTRACT}

This study aims to describe the profile of physical science process skills (KPS) of students in Lubuklinggau City High School on dynamic electrical material. The research subjects were high school class XII students in the odd semester in SMA Negeri 1, MAN 1 Model and SMA Negeri 5 in Lubuklinggau. Sampling is done by purposive sampling. Qualitative Descriptive Method. Data is analyzed qualitatively and quantitatively. Based on the results of research on physics KPS students in class XII IPA on the subject of Dynamic Electricity, it was concluded (1) The skills of physics science process students of class XII IPA on the subject of Dynamic Electricity are skilled, and (2) Solutions to solving the availability of aspects of KPS is to train and be trained with the student physics KPS approach so that the availability of aspects of student PPPs can appear / be available. The aspects of PPP that need to be trained and trained are classification skills, communicating, hypothesizing, applying concepts, experimenting, using tools and materials, interpreting and asking questions. The percentage increase in KPS namely, observation skills $90.3 \%$, classification skills $85.3 \%$, interpretation skills $87.2 \%$, prediction skills $80.4 \%$, ability to plan experiments or $92.6 \%$ investigation, skills using tools and materials $92,1 \%$, skills to apply concepts or principles $82.3 \%$, communication skills $89.4 \%$, skills to ask questions $95.1 \%$, and hypothesizing skills $81.2 \%$. So that overall there is a significant increase of $87.3 \%$ KPS students. 


\section{Pendahuluan}

Fisika pada hakikatnya bertujuan untuk mengembangkan peserta didik dalam mengenal gejala alam, memahami gejala dan proses kejadian alam yang terjadi secara ilmiah dengan pendekatan metode ilmiah. Hal ini didasari oleh tujuan pembelajaran sains, yakni mengamati, memahami dan memanfaatkan gejala-gejala alam yang melibatkan materi (zat) dan energi. Kemampuan observasi dan eksperimentasi ini lebih ditekankan pada melatih kemampuan berpikir ilmiah yang mencakup melakukan percobaan dalam pengukuran atau membuktikan hipotesis secara ilmiah. Mata pelajaran fisika yang disampaikan melalui proses penyelidikan ilmiah, dapat melatih dan mengembangkan keterampilan proses sains siswa. Hal inilah yang menjadi karakteristik dari pelajaran fisika.

Pembelajaran fisika sangat berperan dalam meningkatkan keterampilan proses sains (KPS) siswa. KPS merupakan pendekatan proses dalam pembelajaran fisika didasarkan atas pengamatan terhadap apa yang dilakukan oleh seorang ilmuwan. Kurikulum 2013 (K-13) sangat tepat dalam menerapkan keterampilan proses sains sehingga pembelajaran fisika mampu mengarahkan pada pengembangan aspek keterampilan misalnya keterampilan dalam memproses pengetahuan, menemukan dan mengembangkan sendiri fakta, konsep, dan nilai-nilai yang diperlukan. Siswa diberikan kesempatan untuk langsung terlibat dalam aktivitas dan pengalaman ilmiah seperti yang dilakukan/dialami oleh ilmuwan. Dengan demikian siswa dididik dan dilatih untuk terampil dalam memperoleh dan mengolah informasi melalui aktivitas berpikir dengan mengikuti prosedur (metode) ilmiah, seperti terampil melakukan pengamatan, pengukuran, merancang dan merakit instrumen percobaan, menguji hipotesis melalui percobaan pengklasifikasian, penarikan kesimpulan, dan pengkomunikasian hasil temuan secara lisan dan tertulis. Tawil, dkk (dalam Saputra, 2015:8) menyatakan bahwa keterampilan proses sains adalah proses dalam melakukan aktivitas-aktivitas sains. Karena sains erat kaitannya dengan persoalan-persoalan seharihari berarti dengan mengajarkan keterampilan proses sains kepada siswa sama artinya dengan mengajarkan keterampilan yang nantinya akan mereka gunakan dalam kehidupan sehari-hari.

Dahar (dalam Pratama, 2015:7) mendefinisikan bahwa keterampilan proses sains adalah kemampuan siswa untuk menerapkan metode ilmiah dalam memahami, memperoleh, atau mengembangkan ilmu pengetahuan. Dari definisi diatas dapat disimpulkan bahwa Keterampilan proses sains merupakan proses kemampuan serta keterampilan yang dimiliki dan diterapkan siswa dalam menerapkan metode ilmiah yakni observasi, klasifikasi, interprestasi, menerapkan konsep, bereksperimen, mengkomunikasikan, berhipotesis, prediksi, menggunakan alat dan bahan, serta mengajukan pertanyaan pada proses belajar.

Conny Semiawan dalam Hilpan (2014) mengungkapkan bahwa ada beberapa alasan yang melandasi perlunya diterapkan pendekatan keterampilan proses dalam kegiatan belajar sehari-hari, yaitu perkembangan ilmu pengetahuan berlangsung semakin pesat sehingga tak mungkin lagi guru mengajarkan semua fakta dan konsep kepada siswa. Siswa akan mudah memahami konsep-konsep yang rumit dan abstrak jika disertai dengan contohcontoh kongkret dan dalam proses belajar mengajar, pengembangan konsep tidak dapat dilepaskan dari pengembangan sikap dan nilai dalam diri siswa. Berdasarkan alasan di atas perlu dicari cara belajar mengajar yang sebaikbaiknya dan kemampuan siswa dalam menemukan konsep perlu dibekali dengan kegiatan pembelajaran yang berorientasi proses (student centered).

Berdasarkan observasi dan wawancara ke guru dan siswa yang dilakukan peneliti di beberapa sekolah di kota Lubuklinggau, fisika masih dipandang sebagai pembelajaran yang menakutkan, banyak rumusan yang harus dihapal, siswa belum menemukan makna, kebermanfaatan ketika diajarkan oleh guru, siswa kesulitan dalam hitung, kesulitan memahami konsep fisika yang diajarkan, masih banyak yang mengalami miskonsepsi dalam belajar fisika khususnya listrik dinamis, penggunaan laboratorium dalam pembelajaran fisika tidak pernah dilakasanakan. Selanjutnya siswa merasa malas untuk membaca bahan teks fisika yang digunakan karena banyak rumusan, 
tidak menarik karena fisika sudah menjadi pelajaran yang menakutkan. Fakta yang ditemukan di lapangan juga menunjukkan bahwa sumber belajar fisika listrik dinamis dalam bahan sekolah elektronik (BSE) masih belum kontekstual dan belum memunculkan keterampilan proses sains peserta didik. Fakta tersebut sejalan dengan pendapat Prastowo (2011) bahwa banyak pendidik yang masih menggunakan bahan ajar konvensional, yaitu bahan ajar tinggal pakai dan tinggal beli tanpa ada upaya menyusun sendiri. Dengan demikian, sangat memungkinkan jika bahan ajar yang digunakan tidak kontekstual, tidak menarik, monoton dan tidak sesuai dengan kebutuhan siswa.

Hosnan (2016:267) menyatakan bahwa pembelajaran kontekstual merupakan konsep belajar dimana guru menghadirkan dunia nyata kedalam kelas dan mendorong siswa membuat hubungan antara pengetahuan yang dimilikinya dengan penerapanya dalam kehidupan seharihari. Yolanda (2014) menyatakan bahwa pembelajaran kontekstual adalah pembelajaran yang mampu membangun kebermaknaan (construktivism), pembelajaran berbasis penemuan (inquiry), belajar bersama (learning community), pembelajaran berdasarkan konteksnya (modelling), penilaiannya autentik dan mampu mengukur tingkat kemampuan siswa (authentic assesment), Memberikan kesempatan kepada siswa untuk bertanya (questioning), dan membimbing siswa dalam mereview kembali materi yang telah diajarkan (reflection). Materi fisika tentang listrik dinamis merupakan materi yang sangat kontekstual, sangat menarik dan bermanfaat dan siswa lebih banyak mengalami dan menemukan listrik sebagai kebutuhan pokok untuk penerangan, menghidupkan alat-alat elekronik yang bisa membantu pekerjaan manusia. Bahan ajar listrik dinamis perlu dikembangkan dalam sebuah bahan ajar berbasis kontekstual, bahan ajar yang praktis, efektif, dan efisien sangatlah penting guna meningkatkan hasil belajar siswa dan meningkatkan keterampilan proses sains siswa, menarik minat siswa untuk membaca dan bisa mengukur pengetahuan, keterampilan dan sikap siswa dalam pembelajaran fisika. Oleh karena itu, untuk meningkatkan mutu pembelajaran Listrik Dinamis perlu dikembangkan bahan ajar berbasis kontekstual.
Sebelumnya peneliti melakukan penelitian tentang Pengembangan bahan ajar Listrik Dinamis yang diimplementasikan skala lokal di sekolah SMA/MA Kota Lubuklinggau yakni SMA Negeri 1 Lubuklinggau, SMA Negeri 5 Lubuklinggau dan MAN 1 Model Lubuklinggau; Hasil penelitian menunjukkan bahwa bahan ajar memenuhi kriteria valid, praktis dan efektif.

Dengan demikian, peneliti bermaksud ingin mendeskripsikan profil keterampilan proses sains siswa di kota lubuklinggga yang menggunakan bahan ajar dengan pendekatan kontekstual yang membahas yang membahas tentang kuat arus, hambatan listrik, rangkaian listrik, alat ukur listrik dan energi listrik.

\section{Metode}

Sugiyono (2013) menjelaskan metode penelitian pada dasarnya merupakan cara ilmiah untuk mendapatkan data dengan tujuan dan kegunaan tertentu. Penelitian ini adalah penelitian deskriptif dengan menggunakan metode kualitatif. Supardi (2015) menjelaskan bahwa penelitian deskriptif pada umumnya dilakukan dengan tujuan utama, yaitu menggambarkan secara sistematis fakta dan karakteristik objek atau subjek yang diteliti secara tepat.

Teknik pengumpulan data menggunakan triangulasi yakni dokumentasi, wawancara dan tes diagnosis KPS. Sumber data dari penelitian ini adalah hasil dari hasil soal tes disgnosis terdapat dalam bahan ajar dan wawancara dilakukan untuk melihat permasalahan KPS disetiap tingkat kemampuan siswa dan memberikan solusi dalam menyelesaikan permasalahan KPS. Lembar wawancara akan divalidasi terdahulu oleh guru mata pelajaran fisika dan dosen program studi fisika. Data yang diperoleh kemudian disusun, dan dianalisis sesuai kemunculan aspek keterampilan proses sains.

Adapun tahap analisis data tersebut adalah sebagai berikut:

1. Obsevasi, Adapun tes diagnosis dan lembar Observasi terdapat pada bahan ajar telah divalidasi oleh ahli ibu Linda Kurniawati, M.Pd. selaku guru fisika dan ibu Wahyu Arini, M.Pd.Si. selaku dosen fisika. 
Yolanda (2015) Analisa KPS penelitian ini dilakukan cara mengukur ketersediaan aspek keterampilan proses sains sebagai berikut (a) Mengubah data kualitatif ke kuantitatif setiap indikator-indikator pada masing-masing aspek uji keterampilan proses sains perlu di beri skor dengan bobot $1,2,3$ dan 4. Setiap respon yang benar diberi skor dengan bobot tertentu, umpamanya masing-masing 1 untuk pokok uji observasi di atas yang berarti jumlah skornya 4. Dan untuk respon yang lebih kompleks, misalnya membuat pertanyaan, dapat diberi skor bervariasi berdasarkan tingkat kesulitannya. Umpamanya pertanyaan berlatar belakang hipotesis diberi skor 3; pertanyaan apa, mengapa, bagaimana diberi skor 2; pertanyaan yang meminta penjelasan diberi skor 1. (b) Setelah melakukan pemberian skor pada setiap indikator ketersedian aspek KPS, selanjutnya kita jumlahkan kemunculan indikator keterampilan proses sains tersebut dan menghitung persentase frekuensi kemunculan seluruh aspek. Selanjutnya (c) Kategorikan aspek keterampilan proses sains siswa ke dalam tabel interpretasi tes diagnostik berikut:

Tabel 1. Interpretasi KPS Fisika siswa pada Bahan Ajar

\begin{tabular}{|l|l|}
\hline $\begin{array}{l}\text { Kategori } \\
\text { Kemampuan } \\
\text { Aspek KPS }\end{array}$ & $\begin{array}{l}\text { Rentang Skor Aspek } \\
\text { KPS }\end{array}$ \\
\hline Tidak Terampil & $10 \leq \mathrm{x} \leq 17,5$ \\
\hline Cukup Terampil & $17,5 \leq \mathrm{x} \leq 25$ \\
\hline Terampil & $25 \leq \mathrm{x} \leq 32,5$ \\
\hline Sangat Terampil & $32,5 \leq \mathrm{x} \leq 40$ \\
\hline
\end{tabular}

2. Melakukan uji validasi oleh dosen ahli mengenai isi dan konstruksi lembar observasi keterampilan proses sains dan validasi instrumen. (a) Tes Diagnostik, Data yang diperoleh dari hasil diagnostik terhadap siswa direduksi dengan siswa dengan mengelompokkan siswa yang menerapkan aspek KPS. Tes yang digunakan pada penelitian ini berupa tes diagnostik dan soal tes LKS, kemudian menganalisis kemunculan aspek KPS pada keduanya. Hilpan (2014) menguraikan cara mengukur ketersedian Aspek Keterampilan Proses Sains dilakukan dengan beberapa cara, yakni mengubah data kualitatif ke kuantitatif setiap indikator-indikator pada masingmasing aspek uji keterampilan proses sains perlu di beri skor dengan bobot 1, 2, 3 dan 4 . Setiap respon yang benar diberi skor dengan bobot tertentu, umpamanya masing-masing 1 untuk pokok uji observasi di atas yang berarti jumlah skornya 4. Dan untuk respon yang lebih kompleks, misalnya membuat pertanyaan, dapat diberi skor bervariasi berdasarkan tingkat kesulitannya. Umpamanya pertanyaan berlatar belakang hipotesis diberi skor 3; pertanyaan apa, mengapa, bagaimana diberi skor 2; pertanyaan yang meminta penjelasan diberi skor 1. (b) Setelah melakukan pemberian skor pada setiap indikator ketersedian aspek KPS, selanjutnya kita jumlahkan kemunculan indikator keterampilan proses sains tersebut dan menghitung persentase frekuensi kemunculan. (c) Kategorikan aspek keterampilan proses sains siswa ke dalam tabel interpretasi tes diagnostik berikut:

Tabel 2. Interpretasi Hasil Tes Diagnostik dengan Reasoning Aspek KPS Fisika siswa

\begin{tabular}{|l|l|}
\hline $\begin{array}{l}\text { Kategori } \\
\text { Kemampuan } \\
\text { Aspek KPS }\end{array}$ & $\begin{array}{l}\text { Rentang Skor Aspek } \\
\text { Tidak Terampil }\end{array}$ \\
\hline Kurang Terampil & $0 \leq \mathrm{x} \leq 10$ \\
\hline Cukup Terampil & $32,5 \leq \mathrm{x} \leq 32,5$ \\
\hline Terampil & $55 \leq \mathrm{x} \leq 77,5$ \\
\hline Sangat Terampil & $77,5 \leq \mathrm{x} \leq 100$ \\
\hline
\end{tabular}

3. Melakukan uji validasi oleh dosen ahli mengenai isi dan konstruksi lembar observasi keterampilan proses sains dan validasi instrumen. Pada penelitian KPS ini, bahwa instrumen penelitian termasuk tes diagnostik, lembar kerja siswa (LKS), lembar observasi aspek keterampilan proses sains (KPS) dan pedoman wawancara telah divalidasi oleh ahli yaitu dosen pendidikan fisika STKIP-PGRI Lubuklinggau bapak Endang Lovisia, M.Pd.Si dan ibu Tri Ariani, M.Pd.Si. (a) Wawancara, Wawancara dilakukan oleh siswa untuk melihat permasalahn KPS di setiap tingkat kemampuan siswa menggunakan pedoman wawancara yang sudah disiapkan oleh 
peneliti. Pedoman wawancara telah divalidasi selanjutnya data wawancara dikumpulkan, informasi yang didapat dianalisis dengan memberikan deskripsi berdasarkan masing-masing aspek. Keterampilan Proses Sains (KPS) untuk kemudian menganalisis kemunculan indikator KPS.

4. Display Data, setelah data direduksi, maka langkah selanjutnya adalah mendisplaykan data. Dalam penelitian kualitatif, penyajian data bisa dilakukan dalam bentuk uraian singkat, bagan, hubungan antar kategori, flowchart dan

5. sejenisnya. Display data paling sering digunakan untuk menyajikan data dalam penelitian kualitatif adalah dengan teks yang bersifat naratif. Miles dan Huberman (dalam Sugiyono, 2014) menyarankan dalam melakukan display data, selain dengan teks yang naratif, juga dapat berupa grafik, matrik, network (jejaring kerja), dan chart. Dalam penelitian ini, display data dilakukan dengan mentabulasikan data berdasarkan kelompoknya masing-masing.

Pada penelitian ini, penyajian data (display data) dilakukan dengan mentabulasikan data dengan menggunakan diagram kolom, tabel, dan gambar berdasarkan kategori masing-masing siswa berkemampuan tinggi (KT), berkemampuan sedang (KS), dan berkemampuan rendah (KR). Penyajian data pada hasil tes diagnostik dengan reasoning siswa terdiri dari interprestasi hasil tes diagnostik aspek KPS, hasil tes diagnostik dengan reasoning siswa, persentase hasil tes diagnostik dengan reasoning siswa rata-rata persentase hasil tes diagnostik dengan reasoning siswa, dan hasil jawaban tes diagnostik dengan reasoning aspek KPS siswa.
Penyajian data pada hasil observasi yang dilakukan observer terdiri dari interprestasi observasi aspek KPS, hasil observasi aspek KPS fisika siswa, dan persentase hasil observasi aspek KPS. Penyajian data terdiri dari ketersediaan aspek KPS, sehingga data yang disajikan akan lebih jelas dan mudah dipahami.

\section{Hasil dan pembahasan}

Hasil (1) Keterampilan proses sains fisika siswa pokok bahasan listrik dinamis adalah terampil, dan (2) Solusi untuk menyelesaikan permasalahan ketersediaan aspek KPS adalah melatih dan dilatih dengan pendekatan KPS fisika siswa agar ketersediaan aspek KPS siswa dapat muncul/tersedia. Adapun aspek KPS yang perlu dilatih dan melatih adalah keterampilan klasifikasi, mengkomunikasikan, berhipotesis, menerapkan konsep, bereksperimen, menggunakan alat dan bahan, interprestasi dan mengajukan pertanyaan. Persentase peningkatan KPS yakni, keterampilan observasi 90,3\%, keterampilan klasifikasi 85,3\%, keterampilan interpretasi $87,2 \%$, keterampilan prediksi 80,4 \%, keterapilan merencanakan percobaan atau penyelidikan 92,6\%, keterampilan menggunakan alat dan bahan $92,1 \%$, keterampilan menerapkan konsep atau prinsip $82,3 \%$, keterampilan berkomunikasi $89,4 \%$, keterampilan mengajukan pertanyaan 95,1\%, dan keterampilan berhipotesis $81,2 \%$. Sehingga secara keseluruhan terjadinya peningkatan yang signifikan 87,3\% KPS siswanya.

Untuk pembahasan sebagai solusi dalam mengatasi permasalahan keterampilan proses sains siswa dapat dilihat pada tabel 4 yang dibahas pada setiap aspek.

Tabel 3. Hasil KPS

\begin{tabular}{|l|c|}
\hline \multicolumn{1}{|c|}{ Aspek KPS } & Rata-rata \\
\hline Observasi & $90,3 \%$ \\
\hline Klasifikasi & $85,3 \%$ \\
\hline Mengajukan pertanyaan & $95,1 \%$ \\
\hline Mengkomunikasikan & $89,4 \%$ \\
\hline Berhipotesis & $81,2 \%$ \\
\hline Prediksi & $80,4 \%$ \\
\hline Merencanakan percobaan/ bereksperimen & $82,6 \%$ \\
\hline Menggunakan alat dan bahan & $92,1 \%$ \\
\hline Menerapkan konsep & $82,3 \%$ \\
\hline Interprestasi & $87,2 \%$ \\
\hline
\end{tabular}


Tabel 4. Permasalahan dan Solusi

\begin{tabular}{|c|c|}
\hline Permasalahan & Solusi \\
\hline \multicolumn{2}{|l|}{ Keterampilan Klasifikasi } \\
\hline $\begin{array}{l}\text { Siswa tidak terampil dalam membedakan rangkaian } \\
\text { hambatan yang tersusun secara seri dan paralel }\end{array}$ & $\begin{array}{l}\text { Guru harus memberikan modelling dan menjelaskan } \\
\text { secara inkuiri susunan hambatan secara seri dan } \\
\text { paralel secara repitisi. }\end{array}$ \\
\hline \multicolumn{2}{|l|}{ Keterampilan Mengkomunikasikan } \\
\hline $\begin{array}{l}\text { a) Siswa tidak terampil dalam membaca grafik dan } \\
\text { tabel hubungan arus dan tegangan pada listrik } \\
\text { dinamis } \\
\text { b) Siswa mengalami kesulitan membaca gambar } \\
\text { rangkaian listrik tertutup dengan penerapan } \\
\text { hukum II Kirchoff tentang Loop. }\end{array}$ & $\begin{array}{l}\text { a) Guru membimbing siswa membaca grafik dan } \\
\text { menarik kesimpulan dari grafik dan tabel } \\
\text { hubungan arus dan tegangan. } \\
\text { b) Guru membimbing siswa memperbanyak latihan } \\
\text { soal tentang analisa gambar rangkaian listrik } \\
\text { tertutup dengan penerapan hukum II Kirchoff } \\
\text { tentang Loop dengan cara dikomunikasikan } \\
\text { dalam penyelesaian kasus. }\end{array}$ \\
\hline \multicolumn{2}{|l|}{ Keterampilan Berhipotesis } \\
\hline $\begin{array}{l}\text { Siswa tidak terampil dalam membuktikan nilai } \\
\text { hambatan pengganti yang terkecil, nilai arus dan } \\
\text { tegangan masing-masing hamabatan dari susunan } \\
\text { rangkaian hambatan seri dan paralel. }\end{array}$ & $\begin{array}{l}\text { Guru memberikan petunjuk serta arahan mengenai } \\
\text { hipotesis percobaan dalam membuktikan nilai } \\
\text { hambatan pengganti yang terkecil, nilai arus dan } \\
\text { tegangan masing-masing hamabatan dari susunan } \\
\text { rangkaian hambatan seri dan paralel. }\end{array}$ \\
\hline \multicolumn{2}{|l|}{ Keterampilan Menerapkan Konsep } \\
\hline $\begin{array}{l}\text { Siswa tidak terampil menyelesaikan soal dalam } \\
\text { menerapkan konsep hukum I dan II Kirchoff dalam } \\
\text { rangkaian hambatan seri dan paralel. }\end{array}$ & $\begin{array}{l}\text { Guru membimbing siswa sesuai dengan tingkat } \\
\text { kesulitan belajar siswa dalam meyelesaikan soal-soal } \\
\text { yang menerapkan konsep hukum I dan II Kirchoff } \\
\text { dalam rangkaian hambatan seri dan paralel. }\end{array}$ \\
\hline \multicolumn{2}{|l|}{ Keterampilan Bereksperimen } \\
\hline $\begin{array}{l}\text { a) Siswa tidak terampil dalam menyusun langkah- } \\
\text { langkah percobaan listrik dinamis susunan } \\
\text { hambatan secara seri dan palael. } \\
\text { b) Siswa belum paham bagaimnan menghitung } \\
\text { biaya tagihan listrik berdasarkan analisa } \\
\text { pemakaian. }\end{array}$ & $\begin{array}{l}\text { a) Guru membimbing siswa dengan cara } \\
\text { demonstrasi alat-alat praktikum sehingga siswa } \\
\text { siap melakukan percobaan listrik dinamis } \\
\text { susunan hambatan secara seri dan palael. } \\
\text { b) Guru membimbing siswa untuk memahami } \\
\text { menghitung biaya tagihan listrik berdasarkan } \\
\text { analisa pemakaian. }\end{array}$ \\
\hline \multicolumn{2}{|l|}{ Keterampilan Menggunakan Alat dan Bahan } \\
\hline $\begin{array}{l}\text { Siswa tidak terampil dalam menyebutkan prosedur } \\
\text { pengukuran yakni kalibrasi alat ukur, prosedur } \\
\text { mengukur arus DC, mengukur tegangan dan } \\
\text { hambatan pengganti menggunakan multimeter }\end{array}$ & $\begin{array}{l}\text { Guru menjelaskan dan mempraktikkan secara } \\
\text { langsung prosedur kalibrasi alat ukur, prosedur } \\
\text { mengukur arus DC, mengukur tegangan dan } \\
\text { hambatan pengganti menggunakan multimeter }\end{array}$ \\
\hline \multicolumn{2}{|l|}{ Keterampilan Interprestasi } \\
\hline $\begin{array}{l}\text { Siswa tidak terampil dalam menyimpulkan hasil } \\
\text { percobaan rangkaian hambatan seri danrangkaian } \\
\text { hambatan paralel }\end{array}$ & $\begin{array}{l}\text { Siswa terampil dalam menginterpetasikan hasil data } \\
\text { percobaan dalam grafik hubungan tegangan V dan } \\
\text { arus I pada susunan hambatan seri dan susunan } \\
\text { hambatan paralel. }\end{array}$ \\
\hline \multicolumn{2}{|l|}{ Keterampilan Mengajukan Pertanyaan } \\
\hline Siswa merasa enggan untuk bertanya & $\begin{array}{l}\text { Siswa sudah berani dan aktif bertanya dengan guru } \\
\text { pembimbing dalam prosedur melakukan percobaan, } \\
\text { menganalisa data dan menginterpretasi hasil } \\
\text { pengukuran dengan bertanya kepada guru. }\end{array}$ \\
\hline
\end{tabular}




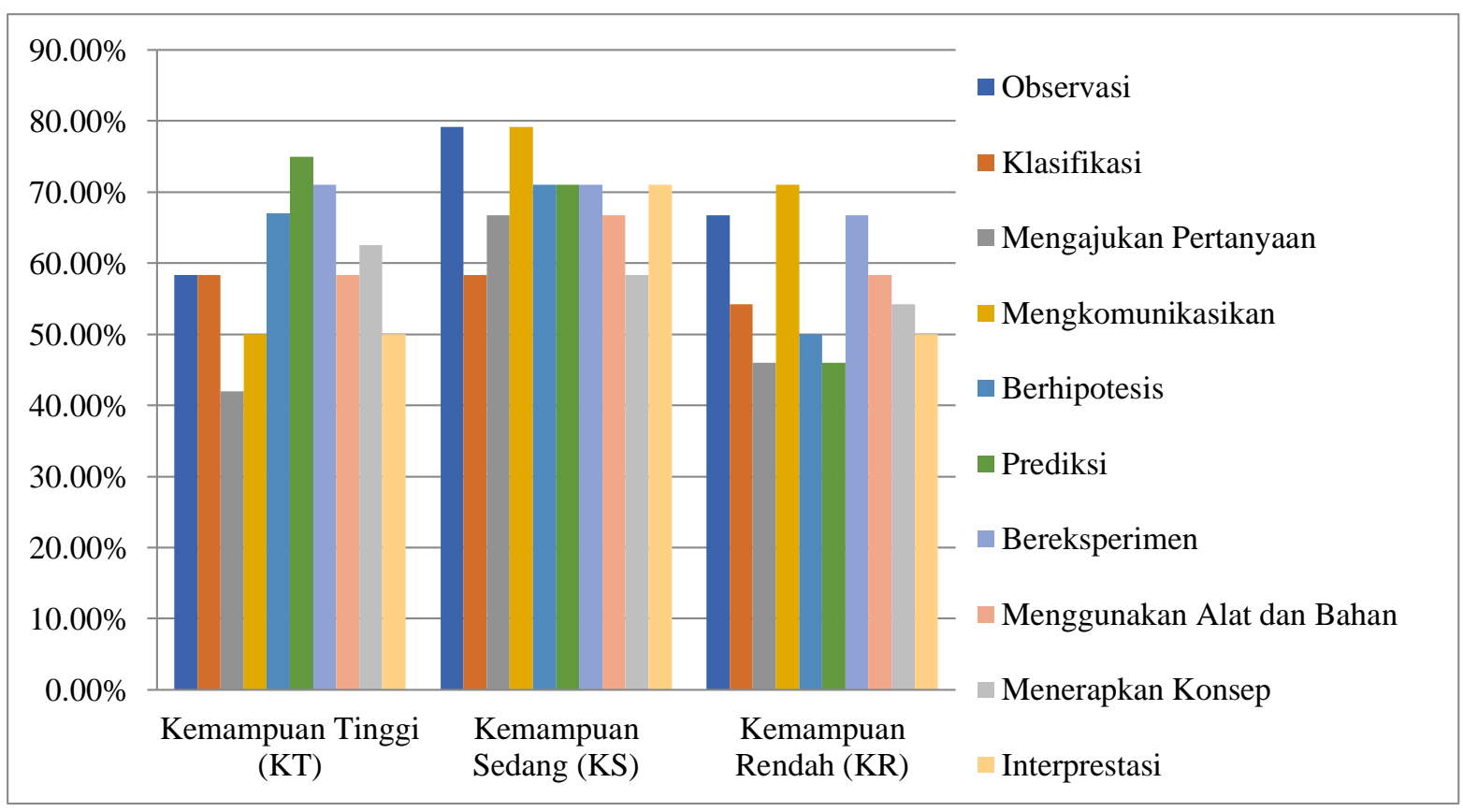

\section{Gambar 1. Grafik persentase perbandingan hasil observasi aspek KPS fisika siswa KT, KS, dan KR}

Hasil observasi yang telah dilakukan pada subjek penelitian yang terdiri dari siswa berkemampuan tinggi, kemampuan sedang, dan berkemampuan rendah memiliki perbedaan, maka untuk itu peneliti membandingkan dari ketiganya. Perbandingan hasil persentase aspek KPS siswa berkemampuan sedang lebih mendominasi 10 aspek KPS dengan jumlah persentase tertinggi pada aspek mengkomunikasi dan observasi. Pada kemampuan tinggi aspek KPS tertinggi pada aspek prediksi dan bereksperimen. Sedangkan pada kemampuan rendah aspek KPS tertinggi pada mengkomunikasi dan observasi.

Sejalan dengan yang disampaikan penelitian terdahulu yakni Yolanda (2015) menafsirkan bahwa keterampilan proses sains akan membangun keterampilan dasar ilmuwan peserta didik. Karena KPS menuntun siswa agar terampil dalam membangun pengetahuan berdasarkan metode riset metode ilmiah baik dengan percobaan ataupu studi literatur. Begitupun juga, Nurhasanah (2016) menjelaskan bahwa apabila KPS ini dikembangkan, siswa akan menemukan konsep dan dapat meningkatkan hasil belajar siswa karena mempunyai beberapa alasan. Pertama, perkembangan ilmu pengetahuan berlangsung secara cepat sehingga tidak mungkin lagi peran guru mengajarkan semua fakta dan konsep kepada siswa. Kedua, siswa mudah memahami konsep yang rumit dan abstrak jika disertai dengan contoh-contoh yang konkret. Ketiga, penemuan ilmu pengetahuan tidak bersifat mutlak benar seratus persen, penemuannya bersifat relatif. Keempat, proses belajar mengajar seyogyanya pengembangan konsep yang tidak lepas dari pengembangan sikap dan nilai dari dalam diri siswa.

\section{Simpulan}

Berdasarkan hasil data penelitian keterampilan proses sains fisika siswa kelas XII IPA pada pokok bahasan Listrik Dinamis disimpulkan (1) Keterampilan proses sains fisika siswa kelas XII IPA pada pokok bahasan listrik dinamis adalah terampil, dan (2) Solusi untuk menyelesaikan permasalahan ketersediaan aspek KPS adalah melatih dan dilatih dengan pendekatan keterampilan proses sains fisika siswa agar ketersediaan aspek keterampilan proses sains siswa dapat muncul/tersedia. Adapun aspek KPS yang perlu dilatih dan melatih adalah keterampilan klasifikasi, mengkomunikasikan, berhipotesis, menerapkan konsep, bereksperimen, menggunakan alat dan bahan, interprestasi dan mengajukan pertanyaan. Persentase peningkatan KPS yakni, keterampilan observasi 90,3\%, keterampilan klasifikasi $85,3 \%$, keterampilan interpretasi $87,2 \%$, keterampilan prediksi $80,4 \%$, keterapilan 
merencanakan percobaan atau penyelidikan $92,6 \%$, keterampilan menggunakan alat dan bahan 92,1\%, keterampilan menerapkan konsep atau prinsip 82,3\%, keterampilan berkomunikasi $\quad 89,4 \%$, keterampilan mengajukan pertanyaan $95,1 \%$, dan keterampilan berhipotesis $81,2 \%$. Sehingga secara keseluruhan terjadinya peningkatan yang signifikan $87,3 \%$ KPS siswanya.

\section{Ucapan terima kasih}

Puji syukur penulis ucapkan kehadirat Allah SWT, karena berkat rahmat dan RidhoNya penulis dapat menyelesaikan penyusunan penelitian yang berjudul "pengembangan Bahan Ajar Fisika Listrik Dinamis Berbasis Kontekstual Terintegrasi Keterampilan Proses Sains".

Penelitian ini disusun dalam mengikuti Program Hibah Penelitian dari Kemenristek Dikti tahun usulan 2017 dan tahun pelaksanaan 2018. Penyusunan penelitian ini tidak terlepas dari bimbingan dan dukungan berbagai pihak. Oleh karena itu, pada kesempatan ini penulis menyampaikan rasa terima kasih kepada:

1. Bapak Dr. H. Rudi Erwandi, M.Pd., selaku Ketua STKIP-PGRI Lubuklinggau atas jasanya yang selalu memberikan dukungan dan intruksi langsung kepada dosen-dosen untuk mengikuti kegiatan hibah penelitian.

2. Bapak Viktor Pandra, M.Pd., selaku Ketua LP4MK yang telah memberikan motivasi dan pendampingan kepada dosen-dosen dari awal proses pengajuan proposal, pendanaan, dan laporan kemajuan penelitian dosen pemula ini terwujud.

3. Ibu Tri Ariani, M.Pd.Si., selaku Ketua Program Studi Pendidikan Fisika yang telah bersedia meluangkan waktu untuk memberikan arahan, bimbingan dan motivasi sehingga penulis dapat menyelesaikan laporan ini dengan baik.

4. Bapak Ahmad Amin, M.Pd.Si., selaku anggota peneliti skema penelitian dosen pemula yang telah bersedia meluangkan waktu untuk mendampingi, melakukan penelitian bersama-sama, membuat laporan dan mengelolah data sehingga selesainya penelitian ini.

5. Ibu Ida Kurnia, M.Pd., Ibu Linda Kurniawati, M.Pd., Bapak Juniyanto, M.Pd., Ibu Wahyu Arini, M.Pd.Si., dan Ibu Dr. Yohana Satinem, M.Pd., sebagai validator bahan ajar yang telah meluangkan waktunya untuk memvalidasi bahan ajar listrik dinamis ini sehingga bahan ajar tersebuk layak digunakan sebagai instrumen penelitian.

6. Anak-anak mahasiswa Program Studi Pendidikan Fisika di STKIP-PGRI Lubuklinggau yang telah banyak membantu sebagai observer dalam pelaksanaan penelitian ini.

\section{Referensi}

Hilpan, Mochammad. 2014. Analisis Ketersediaan Keterampilan Proses Sains (KPS) dalam Buku Sekolah Elektronik (BSE) Fisika Kelas XI pada Konsep Fluida. Jurnal Pendidikan, 2, 24-48.

Hosnan, M. 2016. Pendekatan Saintifik dan Kontekstual Dalam Pembelajaran Abad 21. Bogor: Ghalia Indonesia.

Komalasari, Kokom. 2010. Pembelajaran Kontekstual Konsep dan Aplikasi. Bandung: PT Refika Aditama.

Nurhasanah. 2016. Jurnal Penggunaan Tes Keterampilan Proses Sains (KPS) Siswa dalam Pembelajaran konsep Kalor dengan Model Inquiri Terbimbing. 2 (12), 17-18.

Pratama, Hutomo Eri. 2015. Jurnal Keterampilan Proses Sains Siswa Jurusan IPA Beberapa SMA di Yogyakarta. ISSN: 2252-9454, 1017. 
Saputra, Andika W. 2015. Analisis Keterampilan Proses Sains Siswa Sekolah Menengah Atas (SMA) di Kecamatan Andong Kabupaten Boyolali pada Mata Pelajaran Fisika. 6 (2), 815.

Sugiyono. 2010. Statiska Untuk Penelitian. Bandung: Alfabeta.

Sugiyono. 2008. Metode Penelitian Pendidikan: Pendekatan Kuantitatif, Kualitatif, dan $R$ \& $D$. Bandung: Alfabeta.

Supardi. 2015. Penilaian Autentik Pembelajaran Afektif, Kognitif dan Psikomotor. Jakarta: Rajawali Pers

Yolanda, Y. 2014. Kualitas Batu Bata Campuran Kotoran Sapi Serta Implementasinya Pada Pembelajaran Fisika Materi Tekanan Menggunakan Pembelajaran Dengan Pendekatan CTL di SMP Negeri 1 Lubuklinggau. Tesis tidak diterbitkan. Universitas Bengkulu

Yolanda. Y. 2015. Keterampilan Proses Sains Sebagai Penilaian Pembelajaran Sebagai implementasi Kurikulum 2013. Lubuklinggau. Prosiding Seminar Nasional Matematika II, p2 